\title{
Research on the Socialized Service Mode of University Library
}

\author{
Fu Min \\ Jiangsu Institute of Commerce, Jiangsu Nanjing, China, 211168 \\ Keywords: university library; socialized service; service mode \\ Abstract: This paper analyzes the actual situation of university libraries providing services \\ to the public, and puts forward some principles to follow in the process of opening to the \\ public, and gradually open the contents and scope of the service. On this basis, the \\ socialization orientation of university library is analyzed, and the socialization service \\ mode of university library is explored based on the subject and content of socialization \\ service.
}

\section{Introduction}

Providing services for the opening of the society in university libraries is a measure to conform to the times and development, and also a requirement for the sustainable development of libraries. At present, the degree of socialization of University Libraries in China is relatively low. Whether university libraries should provide social services and how to provide social services are still in the initial stage of theoretical research and practical development. The author searches the existing literature and finds that the literature related to the two themes of "university library" and "socialization" has shown a rising trend year by year, and has shown a sharp increase since 2009. The research mainly focuses on the choice of socialization mode and socialization path. However, if the two themes of "university library" and "social service model" are searched, only 73 relevant documents are available, which shows that the current academic research on the social service model of university libraries is less. Therefore, based on the principle of socialized service of the university library, this paper analyzes the social orientation of its socialized service, and then explores its service mode of carrying out socialized service.

\section{The principles of socialized service in University Libraries}

Based on the current development of University libraries, resources cannot be fully shared and cannot be fully open to the community. University libraries should follow certain principles according to their own actual conditions and gradually promote the expansion of the scope and content of opening to the outside world.

\subsection{The principle of priority in school}

When university libraries provide social services, we should first clarify the relationship between 
campus services and social services. ${ }^{[1]}$ With the increasing demand of the public for culture, the demand for libraries is also gradually increasing. Therefore, university libraries should re-orientate themselves and strengthen their service consciousness to the public in order to improve the social influence of libraries. However, it should also be noted that the primary task of university libraries is to provide teaching and scientific research literature and information needs for teachers and students. Therefore, in the process of social service in University libraries, we should adhere to the principle of "giving priority to the campus" and meet the needs of the public on the basis of meeting the needs of teachers and students.

\subsection{Step by step principle}

It needs a gradual process for the university library to provide social service. In terms of service scale and level, university libraries should gradually move forward. According to their own resources and library environment, university libraries should gradually open to the society in accordance with the principle of gradual progress, so as to ensure the socialization of University libraries. Steady progress. ${ }^{[2]}$

\subsection{The principle of demand orientation}

In the process of providing services, university libraries should adhere to the user centered approach. The public's demand for academic resources of libraries is often less than that of teachers and students. Therefore, in the process of providing social services, libraries of colleges and universities should attach importance to both conventional and academic needs, as well as the needs of the public and academic research. ${ }^{[3]}$ Only by adhering to the principle of demand-oriented in the actual work process can the services provided in the library meet the needs of readers and provide better services for readers. ${ }^{[4]}$

\section{The university library socialization localization analysis}

The funds for the purchase of literature resources, equipment and space decoration by university libraries mainly come from the school appropriation, which is essentially public finance. Therefore, university libraries should assume the obligation and responsibility of serving the whole society because they are defined as social wealth. The social orientation of university libraries is the precondition to promote the socialization of University libraries. The author thinks that university libraries should have the following social orientation:

\subsection{The government think tank}

At present, the information of local governments is relatively scattered, and there is no special organization to collate and study the government information. University libraries should take the initiative to contact with government departments and undertake the management of huge government information. ${ }^{[5]}$ According to the actual information needs, the government information is allocated, and the information of different government departments is classified and aggregated to optimize the allocation of government information resources in order to build a scientific government information service platform. ${ }^{[6]}$ On this basis, university libraries should rely on their professional advantages to dig up government information, so as to find valuable information for government work, and according to the corresponding information to find problems and put forward countermeasures to solve them, and according to the information to provide corresponding reports for government departments to provide reference, give full play to university books. The think tank 
function of the library. ${ }^{[7]}$

\subsection{Social Education Centre}

University libraries providing social services should shoulder the responsibility of social education center with public libraries, and give full play to the functions of social education. In order to meet the needs of this responsibility, university libraries should establish a learning environment combining entity learning space with virtual learning space in the process of social service, open the library entity space such as the lecture hall for social readers, and provide the necessary places for social education. ${ }^{[8]}$ At the same time, we should open the digital resources system of the library to the readers of the society, so that the readers of the society can receive the services of network sharing resources, distance education and so on. Through the wider virtual learning space, university libraries can truly become the center of social education, play the role of social education, and then realize the equal social value.

\section{Probes into the socialization service mode of the university library}

College libraries should actively look for the entry point of socialized service mode, exploit the spatial structure of socialized service by giving full play to its advantages in resources, technology and service, and actively innovate the mode and mechanism of socialized service. ${ }^{[9]}$ The author holds that the socialized service mode of the university library should not be independent and single, but should be a system of socialized service which combines many modes and combines with its own characteristics.

\subsection{Agent based service mode}

\subsubsection{Self-built mode}

Independent self-modeling mode means that university libraries should rely on their own human resources, financial resources and information resources and other facilities to carry out social services, which requires that university libraries have relatively strong resources, belonging to a higher level of requirements. In view of the current situation of the development of University Libraries in China, it is very difficult.

\subsubsection{CO construction and sharing mode}

Co-construction and sharing mode mean that university libraries and other units or social groups carry out social services through co-construction and sharing, and the two sides cooperate through complementary advantages and resource sharing. At present, most university libraries choose to adopt this mode to provide social services, mainly including library alliance, school-land coconstruction, Library-enterprise alliance, Association cooperation.

(1) Library Consortia

Library alliance refers to the cooperative development of social services between university libraries and other university libraries or public libraries. In the process of construction, university libraries often carry out the construction of literature information base according to their disciplines. After opening to the society, it is necessary to meet the needs of all aspects of society and meet the information needs of the information demanders with different disciplines. Therefore, it is difficult to meet the needs of a university library alone. Therefore, only through the joint efforts of Libraries in the region to build a regional library alliance, through the alliance of information resources sharing can improve the ability of university libraries to provide literature and information to meet 
all aspects of information needs.

(2) Co Construction of schools and the government

School-gov co-construction refers to the cooperation between university libraries and local government departments to provide social services of University libraries. This cooperation can not only provide a wider range of information resources and deeper levels for the public and government departments, but also obtain corresponding policies and financial support. Such a service mode not only makes up for the shortage of funds in University libraries, but also saves the cost of government departments to obtain literature and information, thus realizing the win-win cooperation between the two sides. LiaoCheng University and LiaoCheng municipal government's co construction of libraries is an early case in China.

\subsection{Content-based service mode}

\subsubsection{Lending service}

Borrowing service is one of the most basic and easiest service modes provided by University libraries. The university library has abundant information resources, and the literature resources in the library have strong specialty. The library can open the books and periodicals with low borrowing rate to the public according to the actual situation of the collection and periodical utilization in the library to meet the needs of the teachers and students. By understanding the needs of community residents, providing personalized services, and at the same time with the community to build theme bookshelves, so that the social services of university libraries into the community.

\subsubsection{Knowledge service}

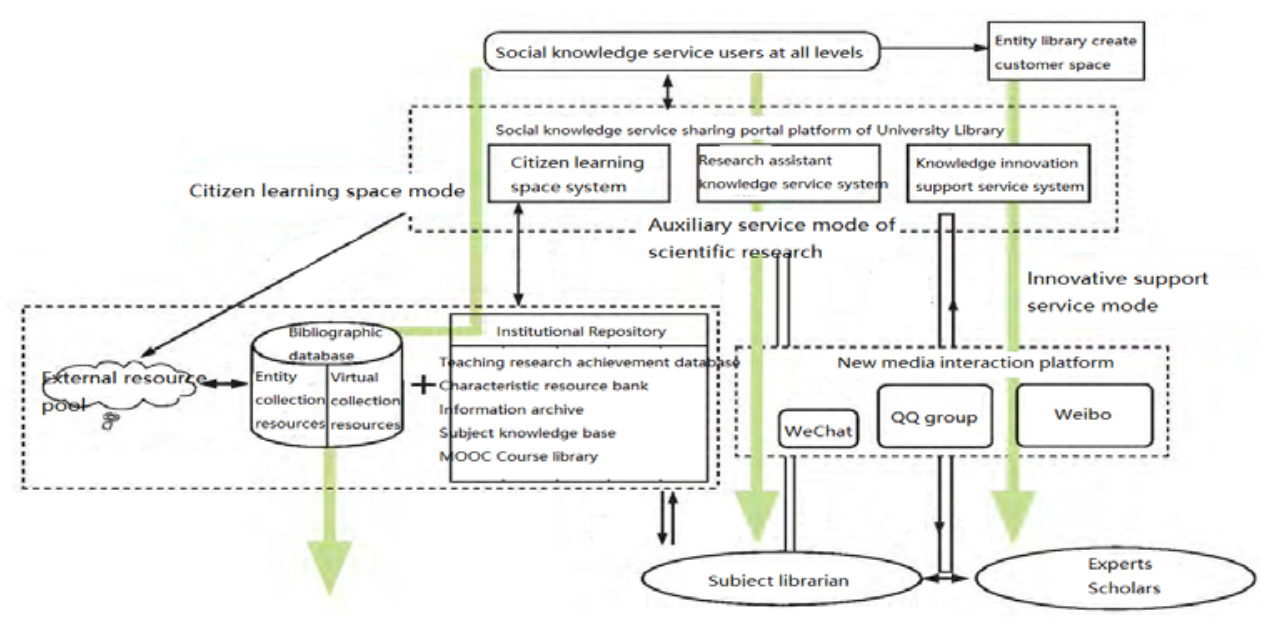

Fig. 1 socialized knowledge service mode of University Library

Knowledge service refers to the knowledge and ability of knowledge service personnel in University libraries, with the help of the equipment in the library to dig deep into the resources in the library and develop a series of more valuable knowledge products, and integrate the products into the whole process of user solving problems. The university library should take the social demand as the service criterion when providing the knowledge service, and achieve specialization and individualization on the basis of providing the high level and deep level knowledge service. University libraries must provide knowledge services in accordance with the requirements of social users, make full use of abundant library resources and combine with advanced technical means, collect relevant information needed by enterprises for decision-making, and provide knowledge services related to policy measures and industry development to form the same situation. It has the 
breadth and depth of high quality knowledge service products. University libraries can try to set up intermediaries for knowledge services, actively explore the social information market, directly participate in the knowledge competition market, provide information consultation and intermediary services for enterprises, and embody the brand-new image of University Libraries in social services.

\section{Conclusions}

The university libraries must choose suitable social service modes based on their own resources, combined with the characteristics of talents, service foundation and service ability in the library. Social service mode is not the only one. Only when multiple social service modes coexist can we provide better service for the society.

\section{References}

[1] S Wang. An Discussion about Some Problems of the Academic Library Socialization [J].Library,2007 .

[2] B Zhang. Theory and Practice of Socialization of University Library Information Service Library of Guangzhou University as an Example[J].Journal of Academic Libraries,2009.

[3] L Waxman, S Clemons, J Banning, D Mckelfresh. The library as place: Providing students with opportunities for socialization, relaxation, and restoration[J].New Library World,2007.

[4] J Wu. Thinking on the Socialization of the Acquisition and Processing in Libraries[J].New Library World,2008.

[5] JL Chen. A Research on the Socialization of Information Service of Academic Library__ A Case Study: Guangzhou University Library, the Information Hall of Guangzhou Government Affairs Center [J]. Library Tribune,2009.

[6] P Zhu. On the Inevitability and Its Implement Pathways for the Service Socialization of University Libraries [J].Library Work in Colleges \& Universities,2005.

[7] Martin Dutch, Dave Muddiman. The Public Library, Social Exclusion and the Information Society in the United Kingdom [J]. De Gruyter,2001(10):183-194.

[8] Sabelo Chizwina. A university library's use of social media during a time of crisis [J]. Library Review,2017(06):2326.

[9] Z Li. Discussion on the Socialization Service Pattern of University Library[J].Journal of Modern Information,2009. 